This document was prepared in conjunction with work accomplished under Contract No. DE-AC09-96SR18500 with the U. S. Department of Energy.

\title{
DISCLAIMER
}

This report was prepared as an account of work sponsored by an agency of the United States Government. Neither the United States Government nor any agency thereof, nor any of their employees, nor any of their contractors, subcontractors or their employees, makes any warranty, express or implied, or assumes any legal liability or responsibility for the accuracy, completeness, or any third party's use or the results of such use of any information, apparatus, product, or process disclosed, or represents that its use would not infringe privately owned rights. Reference herein to any specific commercial product, process, or service by trade name, trademark, manufacturer, or otherwise, does not necessarily constitute or imply its endorsement, recommendation, or favoring by the United States Government or any agency thereof or its contractors or subcontractors. The views and opinions of authors expressed herein do not necessarily state or reflect those of the United States Government or any agency thereof. 


\section{History/Revision Form}

\section{Document Number: WSRC-TR-2004-00514, Rev. 1}

Document Title: Analysis of Tank 48H Samples HTF-E-04-049 and HTF-E-04-050 (August 23, 2004)

Effective Date: May 4, 2005

\section{Document Changes:}

- Changed units for prediction of tetraphenylborate decomposition rate in Tank $48 \mathrm{H}$ from " $0.0898 \mathrm{mg} \mathrm{K} / \mathrm{L} / \mathrm{hr}$ " to " $0.0898 \mathrm{mg} \mathrm{K} / \mathrm{L} /$ day". This number is documented in the $3^{\text {rd }}$ paragraph in the conclusion section on page 14.

- Changed date of report to "May 2005" and changed revision number from " 0 " to " 1 ".

- Deleted extra period in values reported using engineering notation in Tables 7, 8 and Appendix B. For example, changed "2.22.E-01" to "2.22E-01" for Np-237 in Table 7.

- Deleted redundant units in Tables 14 ("M" was listed twice in each row).

- Added units ", mg/L" to title of Table 9.

- All changes were noted using a change bar in the margin of the report. 


\section{ANALYSIS OF TANK 48H SAMPLES HTF-E-04-049 AND HTF-E-04-050 (AUGUST 23, 2004)}

D. P. Lambert

T. B. Peters

M. J. Barnes

S. D. Fink

May 2005

Waste Processing Technology Section Savannah River National Laboratory Aiken, SC 29808 


\section{DISCLAIMER}

This report was prepared by Westinghouse Savannah River Company (WSRC) for the United States Department of Energy under Contract No. DE-AC09-96SR18500 and is an account of work performed under that contract. Neither the United States Department of Energy, nor WSRC, nor any of their employees makes any warranty, expressed or implied, or assumes any legal liability or responsibility for the accuracy, completeness, or usefulness, of any information, apparatus, or product or process disclosed herein or represents that its use will not infringe privately owned rights. Reference herein to any specific commercial product, process, or service by trademark, name, manufacturer or otherwise does not necessarily constitute or imply endorsement, recommendation, or favoring of same by WSRC or by the United States Government or any agency thereof. The views and opinions of the authors expressed herein do not necessarily state or reflect those of the United States Government or any agency thereof.

\section{Printed in the United States of America}

Prepared For

U.S. Department of Energy 
Key Words:

Tank $48 \mathrm{H}$

Cesium

Tetraphenylborate

Retention: Permanent

\section{ANALYSIS OF TANK 48H SAMPLES HTF-E-04-049 AND HTF-E-04-050 (AUGUST 23, 2004)}

D. P. Lambert

T. B. Peters

M. J. Barnes

S. D. Fink

May 2005

Waste Processing Technology Section Savannah River National Laboratory Aiken, SC 29808 


\section{AUTHORS}

\section{REVIEWS AND APPROVALS}

$\begin{array}{lr}\text { D. P. Lambert, author } & 5-12-05 \\ \frac{\text { Thomas B. leters }}{\text { Date }} & 5-12-2005 \\ \text { T. B. Peters, coauthor } & \text { Date }\end{array}$

DESIGN CHECK (per Manual E7, Procedure 2.40)

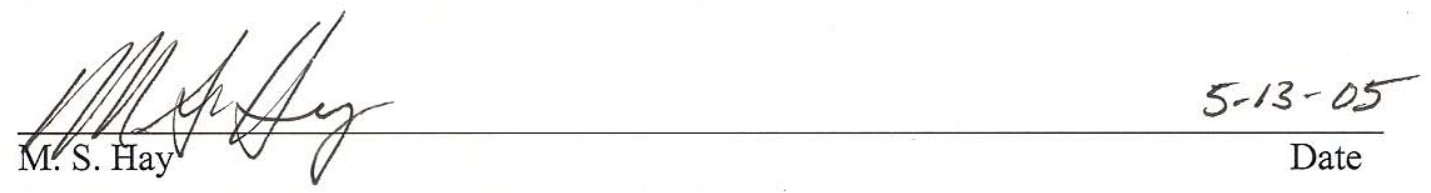

$\frac{\operatorname{Mm} \sum 56}{\text { M. E. Ställings }} \frac{5-12-2005}{\text { Date }}$

\section{APPROVALS}

BCpogas

B. C. Rogers, Technology Manager for Tank 48H

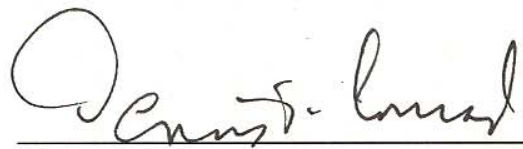

D. T. Conrad, Manager, Low Curie Salt Engineering
$5 / 20105$

Date
$5(23 / 05$

Date
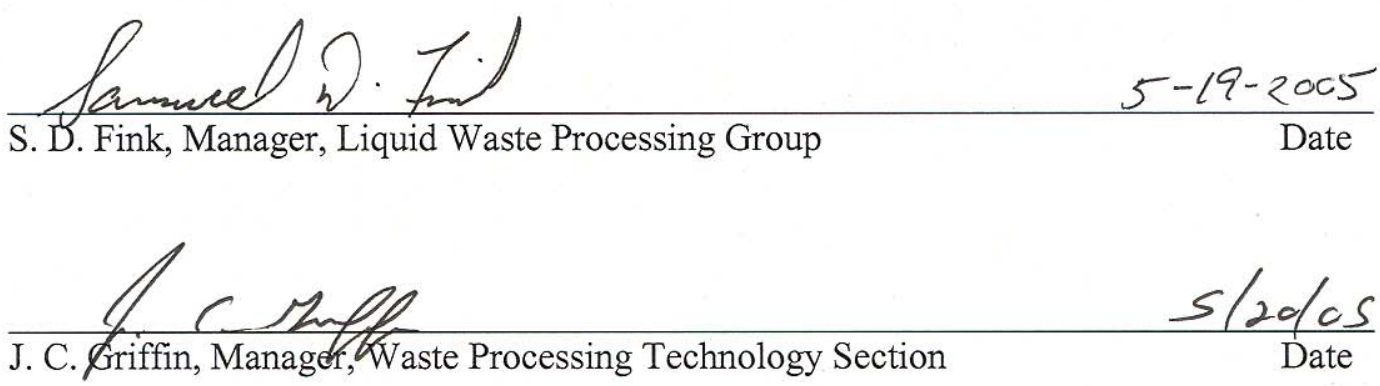


\section{TABLE OF CONTENTS}

Reviews and Approvals ...................................................................................... ii

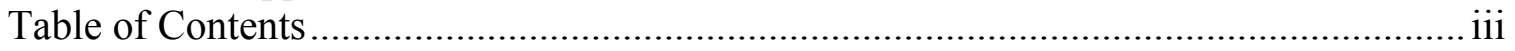

Table of Tables .................................................................................................... iv

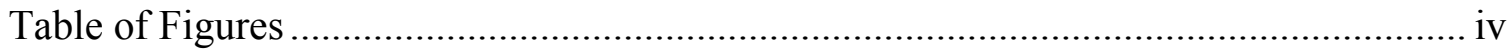

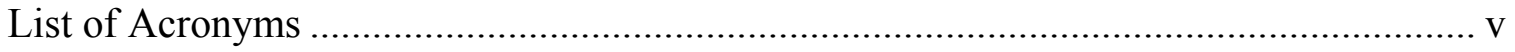

1.0 EXECUTIVE SUMMARY …........................................................................ 1

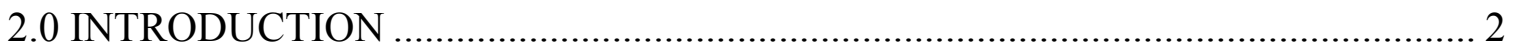

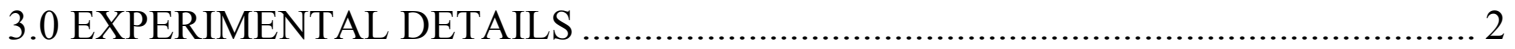

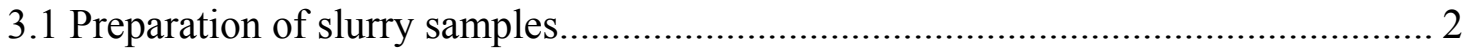

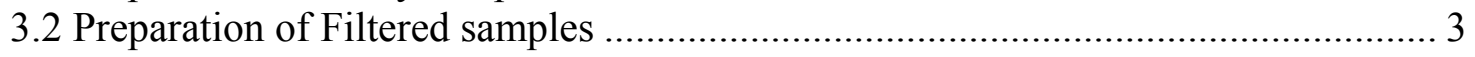

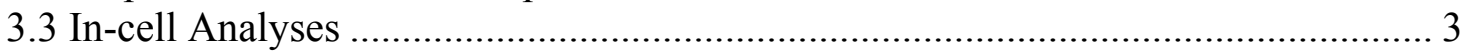

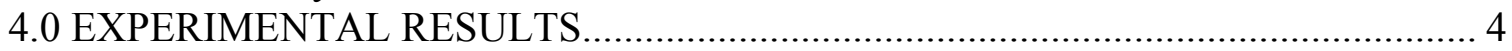

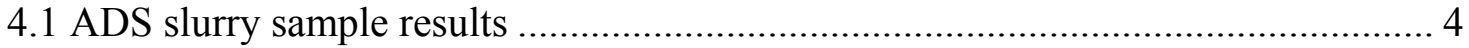

4.1.1 High Performance Liquid Chromatography ................................................... 4

4.1.2 Radionuclide Composition............................................................................. 5

4.1.3 Inductively Coupled Spectroscopy - Emission Spectroscopy …...................... 5

4.1.4 Inductively Coupled Spectroscopy - Mass Spectroscopy …............................ 6

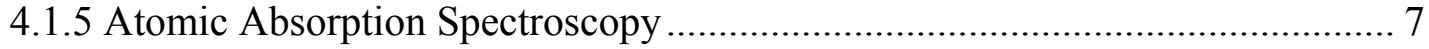

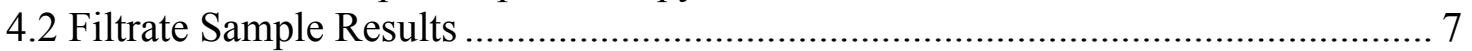

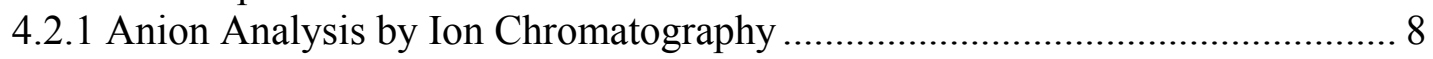

4.2.2 High Pressure Liquid Chromatography ........................................................... 9

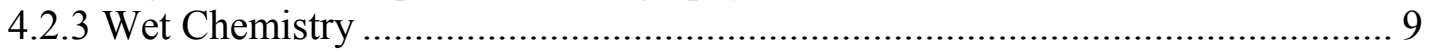

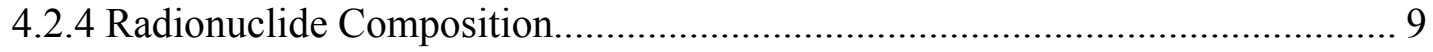

4.2.5 Atomic Absorption Spectroscopy ............................................................. 9

4.2.6 Inductively Coupled Spectroscopy - Emission Spectroscopy ........................ 10

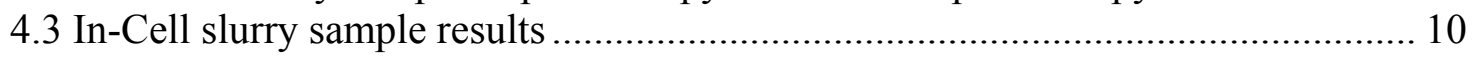

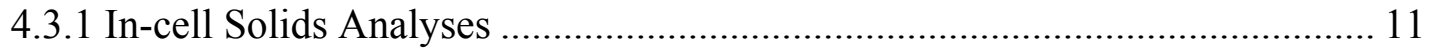

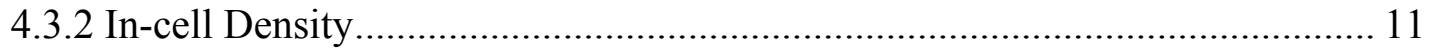

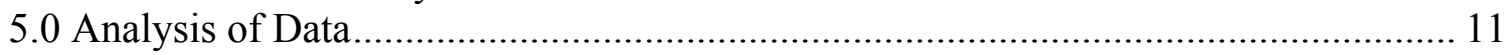

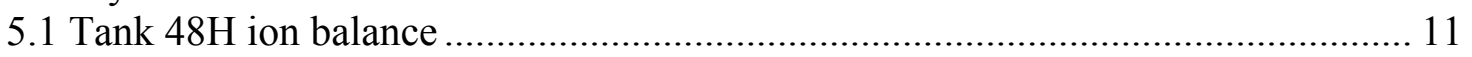

5.2 Tank 48H Soluble Potassium and cesium....................................................... 12

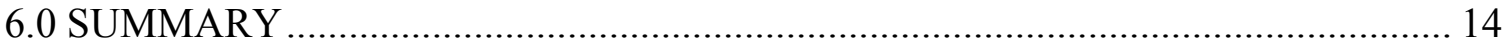

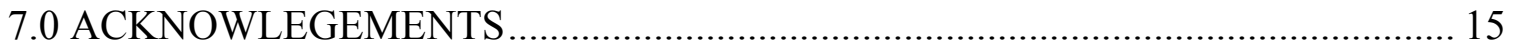

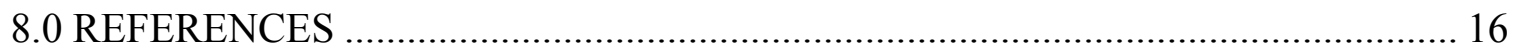




\section{TABLE OF TABLES}

Table 1 - Summary of Significant Tank 48H Sample Results ......................................... 1

Table 2 - Listing of Requested Slurry Analyses and Dilutions....................................... 3

Table 3 - Listing of Requested Filtrate Analyses........................................................... 3

Table 4 - HPLC Slurry Results for the Tank 48H sample .............................................. 5

Table 5 - Tank 48H Slurry Radiation Chemistry Analytical Results............................... 5

Table 6 - Major Elemental Constituents by ICP-ES in the Tank 48H Slurry Sample ....... 6

Table 7 - Actinide Results for the Slurry Sample ........................................................... 7

Table 8 - ICP-MS Catalytic Components Present in the Tank 48H Slurry Sample........... 7

Table 9 - Anion Results for the Filtered Tank 48H sample ........................................ 8

Table 10 - Comparison of Filtrate Anion Values, Molarity ............................................. 8

Table 11 - Tank 48H Filtrate Radiation Chemistry Data .............................................. 9

Table 12 - Radionuclide Comparison with Previous Samples ........................................ 9

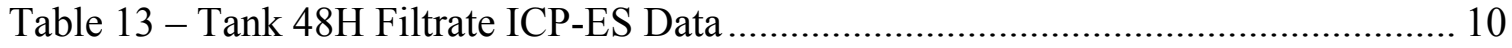

Table 14 - Major Elemental Constituents Present in the Tank 48H Filtrate Sample....... 10

Table 15 - Tank 48H Filtrate Anion/Cation Balance ................................................. 12

\section{TABLE OF FIGURES}

Figure 1 - K Soluble Concentration Increase Due to KTPB Decomposition................... 13

Figure $2-{ }^{137} \mathrm{Cs}$ Concentration Increase Due to CsTPB Decomposition ......................... 14 


\title{
LIST OF ACRONYMS
}

\author{
1PB phenylboronic acid \\ 2PB diphenylborinic acid \\ 3PB triphenylborane \\ 4PB tetraphenylborate anion - $\left[\mathrm{B}\left(\mathrm{C}_{6} \mathrm{H}_{5}\right)_{4}\right]^{-}$ \\ AA Atomic Absorption \\ ADS Analytical Development Section \\ CsTPB Cesium tetraphenylborate $\left(\mathrm{Cs}\left[\mathrm{B}\left(\mathrm{C}_{6} \mathrm{H}_{5}\right)_{4}\right]\right)$ \\ FW Formula Weight \\ HPLC High Performance Liquid Chromatography \\ IC Ion Chromatography \\ ICP-ES Inductively Coupled Plasma - Emission Spectrometry \\ ICP-MS Inductively Coupled Plasma - Mass Spectroscopy \\ ITP In-Tank Precipitation \\ KTPB potassium tetraphenylborate $-\mathrm{K}\left[\mathrm{B}\left(\mathrm{C}_{6} \mathrm{H}_{5}\right)\right]_{4}$ \\ MST monosodium titanate \\ MW Molecular Weight \\ NA Not Applicable \\ NM Not Measured \\ NaTPB Sodium tetraphenylborate $-\mathrm{Na}\left[\mathrm{B}\left(\mathrm{C}_{6} \mathrm{H}_{5}\right)_{4}\right]$ \\ SRNL Savannah River National Laboratory \\ TPB Tetraphenylborate - $\left[\mathrm{B}\left(\mathrm{C}_{6} \mathrm{H}_{5}\right)_{4}\right]^{-}$ \\ WPTS Waste Processing Technology Section
}




\subsection{EXECUTIVE SUMMARY}

Personnel analyzed samples taken from Tank 48H, on August 23, 2004, for chemical and radiological constituents. This report documents the analytical results and analysis of this data.

- The measured potassium tetraphenylborate (KTPB) concentration is $1.95 \pm 0.22 \mathrm{wt} \%$.

- The calculated monosodium titanate (MST) concentration is $0.15 \pm 0.015 \mathrm{wt} \% \mathrm{MST}$.

- The measured insoluble solids content was $1.69 \pm 0.22 \mathrm{wt} \%$. The sum of KTPB and MST is 24\% higher than the insoluble solids concentration. The insoluble solids result is lower than the tank based on previous Tank $48 \mathrm{H}$ analyses.

- The free hydroxide concentration in the Tank $48 \mathrm{H}$ filtrate sample $(1.16 \pm 0.007 \mathrm{M})$ is greater than the Tank $48 \mathrm{H}$ limit $(1.0 \mathrm{M})$. This is an increase of $0.37 \mathrm{M}$ since the September 2003 sample due to the addition of 6,424 gallons of $50 \mathrm{wt} \%$ sodium hydroxide to Tank 48H on October 30, 2003.

- The soluble potassium content in the filtrate continues to follow the linear trend that began in 1995 showing slow, radiolytic decomposition of the tetraphenylborate solids.

- The measured ${ }^{137} \mathrm{Cs}$ concentration is $9.05 \mathrm{E}+08 \pm 1.07+07 \mathrm{dpm} / \mathrm{mL}$ (1.54 Ci/gallon) in the slurry and $2.57 \mathrm{E}+07 \pm 6.01 \mathrm{E}+04 \mathrm{dpm} / \mathrm{mL}$ in the filtrate. This is equivalent to 367,000 total ${ }^{137} \mathrm{Cs}$ curies in Tank $48 \mathrm{H}$. The ${ }^{137} \mathrm{Cs}$ does not follow the earlier linear trend.

- The measured Total Alpha concentration is $1.01 \mathrm{E}+04 \pm 6.51 \mathrm{E}+02 \mathrm{dpm} / \mathrm{mL}$ in the slurry and $2.00 \mathrm{E}+03 \pm 3.891 \mathrm{E}+02 \mathrm{dpm} / \mathrm{mL}$ in the filtrate. This is equivalent to 4.13 total curies from alpha emitters in Tank $48 \mathrm{H}$.

- Three tetraphenylborate decomposition products, triphenylborane (3PB), diphenylborinic acid (2PB), phenylboronic acid (1PB), were all detected in the slurry but not in the filtered sample.

The more significant analytical data is summarized in Table $1_{v}$

Deleted: Table

Table 1 - Summary of Significant Tank 48H Sample Results

\begin{tabular}{|l|c|c|l|}
\hline \multicolumn{1}{|c|}{ Analyte } & Slurry & Supernate & \multicolumn{1}{c|}{ Source } \\
\hline Volume, gal & 239,031 & N/A & Tank 48H \\
\hline Density, g/mL & 1.162 & 1.164 & Density \\
\hline Total Solids, wt \% & $19.08 \%$ & $17.68 \%$ & Solids \\
\hline Total Insolubles, wt \% & $1.69 \%$ & NM & Calculation \\
\hline KTPB, wt \% & $1.95 \%$ & $<0.001 \%$ & HPLC \\
\hline MST solids, wt \% & $0.15 \%$ & NM & ICP-ES \\
\hline Metals \\
\hline Sodium, M & 3.26 & 2.99 & ICP-ES \\
\hline Potassium, M & 0.068 & 0.0065 & AA \\
\hline Anions & \multicolumn{3}{|l|}{} \\
\hline Free Hydroxide, M & NM & 1.155 & Titration \\
\hline Carbonate, M & NM & 0.492 & Titration \\
\hline Nitrite, M & NM & 0.649 & Anion \\
\hline Nitrate, M & NM & 0.304 & Anion \\
\hline RadChem & \multicolumn{4}{|l|}{} & \\
\hline 137 Cs, dpm $/ \mathrm{mL}$ & $9.05 \mathrm{E}+08$ & $2.57 \mathrm{E}+07$ & RadChem \\
\hline Total Alpha, dpm/mL & $1.01 \mathrm{E}+04$ & $2.00 \mathrm{E}+03$ & RadChem \\
\hline
\end{tabular}

NM=Not Measured 


\subsection{INTRODUCTION}

Due to the need for additional HLW storage, successful disposition of the material in Tank $48 \mathrm{H}$ and return of the tank to routine service are two critically needed activities. ${ }^{1}$ As an initial step in the process, SRNL compositionally characterized the components of the Tank $48 \mathrm{H}$ slurry. A nominal Tank 48H Tank 48H slurry sample was collected on August 23, 2004 (HTF-E-04-049 and HTF-E-04-050). The August 23, 2004 sample contained approximately 2 Liters of Tank 48H slurry.

This document provides the chemical and radiological properties of a Tank $48 \mathrm{H}$ slurry sample. A Technical Task Request defines the required analyses ${ }^{2}$. A Task Plan summarized the analyses required and the methods for completing these analyses ${ }^{3}$. The Tank $48 \mathrm{H}$ volume was 239,000 gallons (68.2 inches) at the time of the sampling.

\section{5-L Sample Vessels}

The Tank $48 \mathrm{H}$ team requested collection of two five-liter samples of Tank $48 \mathrm{H}$ slurry material after a minimum of 24 hours of slurry pump operations and immediately after pump shutdown. Sample collection utilized a sampler fabricated by Salt Works.

The total volume of the sampler is 6.54 liters with a liquid fill volume of 4.95 liters. The sample enters the 5-Liter vessel through the inlet port located on the top of the sampler. A crane lowered the sampler approximately 18 inches below the liquid surface. Once filled, the crane raised the sampler to the surface and capped the sampler. The sampler was washed, pulled to the top of the tank, and radiation rates monitored by Radiological Control inspector to confirm the presence of material in the sampler prior to placement in the 8-ton cask. ${ }^{4}$

Collection of the Tank 48H sample occurred on August 23, 2004 by lowering the uncapped 5-L sampler into Tank 48H. Personnel pulled sample HTF-E-04-0049 within 2 minutes of shutting down all four slurry pumps and following 11 hours of continuous operation at full speed (1180 $\mathrm{rpm})$. The four slurry pumps were restarted and operated for an additional 2 continuous hours at full speed $(1180 \mathrm{rpm})$. Personnel pulled sample HTF-E-04-0050 within 8 minutes of shutting down all four slurry pumps. Data concerning the pump operational times, Tank $48 \mathrm{H}$ volume, and seal leakage estimates are summarized in Appendix A.

\subsection{EXPERIMENTAL DETAILS}

Operations shipped two samples to SRNL. Personnel placed the two samplers (HTF-E-03-127) into the shielded cells on August 24, 2004. Technicians emptied the sample vessels, on August 25,2004 , by pumping the contents of the sampler into the calibrated $15-\mathrm{L}$ polypropylene carboy using a peristaltic pump with $1 / 4$ inch Tygon ${ }^{\circledR}$ tubing. The sample was later transferred to a 4-L carboy. Researchers recovered $1.9 \mathrm{~L}$ of slurry from the two samplers. The samplers were sealed after emptying.

\subsection{PREPARATION OF SLURRY SAMPLES}

Personnel diluted the slurry samples as required for analyses. Analysis of all slurry samples occurred in duplicate. Dilution used deionized water while digestion used an acid/hydrogen 
peroxide solution to destroy the organic, dissolve the metals and dilute the samples. Table 2 summarizes the slurry samples submitted for analysis.

Table 2 - Listing of Requested Slurry Analyses and Dilutions

\begin{tabular}{l|ccccc|}
\hline \multicolumn{1}{|c|}{ OPERATION } & Samples & $\begin{array}{c}\text { Sample } \\
\text { Volume, } \mathbf{m L}\end{array}$ & $\begin{array}{c}\text { Dilution } \\
\text { Volume, } \mathbf{m L}\end{array}$ & Diluent & $\begin{array}{c}\text { Tk 48 } \\
\text { Volume, mL }\end{array}$ \\
\hline HLC-DENSITY & 2 & 2 & 0 & None & 4 \\
DISSOLVED SOLIDS (B101) & 2 & 3 & 0 & None & 6 \\
TOTAL SOLIDS (B101) & 2 & 3 & 0 & None & 6 \\
\hline HPLC (B123) & 2 & 2 & 8 & DI Water & 4 \\
\hline GrosS Alpha (B145) & 2 & 0.5 & & & 1 \\
GAMMA SPEC (B145) & 2 & 0.1 & & & 0.2 \\
\hline CVAA HG (B143) & 2 & 1 & Nitric acid Prep in Cells & 2 \\
RAD K by AA & 2 & 1 & & & 2 \\
RAD ICP-ES LCS (B151) & 2 & 1 & & & 2 \\
RADICPMS (B067) & 2 & 1 & &
\end{tabular}

\subsection{PREPARATION OF FILTERED SAMPLES}

Personnel filtered approximately $60 \mathrm{~mL}$ of slurry to produce approximately $50 \mathrm{~mL}$ of filtrate for analysis. Technicians removed a portion of the slurry from the 4-L carboy and filtered it using a $0.45 \mu \mathrm{m}$ supported acrylic copolymer disc filter. They prepared sub-samples from this filtrate without dilution and submitted for analysis as summarized in Table 3.

Table 3 - Listing of Requested Filtrate Analyses

\begin{tabular}{|c|c|c|c|c|c|}
\hline OPERATION & Samples & $\begin{array}{c}\text { Sample } \\
\text { Volume, } \mathrm{mL}\end{array}$ & $\begin{array}{l}\text { Dilution } \\
\text { Volume, } \mathrm{mL}\end{array}$ & Diluent & $\begin{array}{c}\text { Tk } 48 \\
\text { Volume, } \mathrm{mL}\end{array}$ \\
\hline DISSOLVED SOLIDS (B101) & 2 & 1 & 0 & None & 2 \\
\hline HPLC (B123) & 2 & 2 & 0 & None & 4 \\
\hline IC ANIONS LCS (B134) & 2 & 1 & 0 & None & 2 \\
\hline Gross Alpha (B145) & 2 & 0.1 & 9.9 & $.1 \mathrm{M}$ Nitric & \\
\hline GAMMA SPEC (B145) & 2 & 0.1 & 9.9 & $.1 \mathrm{M}$ Nitric & 0.2 \\
\hline RAD ICP-ES LCS (B151) & 2 & 2 & 8 & $.1 \mathrm{M}$ Nitric & 4 \\
\hline RAD $\mathrm{K}$ by $\mathrm{AA}$ & 2 & 2 & 8 & $.1 \mathrm{M}$ Nitric & 4 \\
\hline CARBONATE (B154) & 2 & 1 & 0 & None & 2 \\
\hline $\begin{array}{l}\mathrm{T} \text { BASE/OH/OTHER BASE EXC } \\
\mathrm{CO} 3 \text { (B154) }\end{array}$ & 2 & 1 & 0 & None & 2 \\
\hline
\end{tabular}

\subsection{IN-CELL ANALYSES}

Personnel performed two analyses, each in duplicate, in Shielded Cell Block B to minimize the dose to analytical personnel. Personnel gravimetrically determined the density of the slurry, and gravimetrically determined the total and insoluble solids concentration of the slurry. Note that insoluble solids are defined as those solids that can be removed by filtration, soluble solids are those solids that can not be filtered, and total solids are a sum of the two. These results are reported in wt \% solids on a slurry basis. 
Personnel gravimetrically determined the density of the slurry at ambient Shielded Cells temperature using $2 \mathrm{~mL}$ Class A micro-volumetric flasks.

Technicians gravimetrically determined the total solids by drying portions of the sample to constant mass at $100 \pm 5^{\circ} \mathrm{C}$. They used duplicate analysis of a nominal $15 \mathrm{wt} \% \mathrm{NaCl}$ standard, slurry sample and the filtered filtrate to measure total solids and dissolved solids in the Tank $48 \mathrm{H}$ material. Technicians pre-weighed clean, dry Pyrex ${ }^{\mathrm{TM}}$ beakers for each analysis. Personnel mixed the samples thoroughly, removed $\sim 3 \mathrm{~mL}$ aliquots, and delivered to each beaker (i.e., $3 \mathrm{~mL}$ of the $15 \mathrm{wt} \% \mathrm{NaCl}$ standard to beakers $1-2,3 \mathrm{~mL}$ of Tank $48 \mathrm{H}$ slurry sample to beakers 3-4 and, and $3 \mathrm{~mL}$ of Tank $48 \mathrm{H}$ filtrate to beakers 5-6). Personnel weighed each beaker with sample immediately after addition then proceeded to dry the samples in a $100-115{ }^{\circ} \mathrm{C}$ oven for 8 hours. Samples cooled in a dessicator for $15 \mathrm{~min}$ before additional-weighing. Technicians repeated the drying cycle 3 additional times to ensure complete drying.

\subsection{EXPERIMENTAL RESULTS}

ADS personnel completed the analyses between September 1, 2004 and October 21, 2004. The slurry results are generally reported as $\mathrm{mg} / \mathrm{L}$ of slurry. The filtrate results are reported as $\mathrm{mg} / \mathrm{L}$ filtrate. To convert the filtrate results to a slurry basis, multiply filtrate result, in $\mathrm{mg} / \mathrm{L}$, by $0.981^{*}$. This correction is necessary to compare the filtrate and slurry results to determine the insoluble solids concentration. The results are reported in this section and discussed in Section 5.0, Analysis of Data.

\subsection{ADS SLURRY SAMPLE RESULTS}

ADS personnel analyzed the diluted or digested slurry in duplicate. We report the analytical data, together with the one standard deviation $(1 \sigma)$ uncertainty.

\subsubsection{High Performance Liquid Chromatography}

HPLC analysis is used to detect TPB, phenylborates (3PB, 2PB, and 1PB), phenol, and other TPB decomposition products. HPLC analysis of a Tank $48 \mathrm{H}$ slurry sample provided detectable quantities of TPB, triphenylborane (3PB), diphenylborinic acid (2PB), phenylboronic acid (1PB) nitrobenzene, phenol and biphenyl (Table 4). Less than detectable quantities $(<50 \mathrm{mg} / \mathrm{L})$ of nitrosobenzene, 4-phenylphenol, 2-phenylphenol, diphenylamine, o-terphenyl, m-terphenyl, and p-terphenyl existed. The KTPB concentration is $22,600 \mathrm{mg} / \mathrm{L}$ or $1.95 \pm 0.22 \mathrm{wt} \%$ assuming all the TPB is present as KTPB.

The prior Tank 48H sample (September 2003) did not have a detectable concentration of 3PB, $2 \mathrm{~PB}$ or $1 \mathrm{~PB}$ (each has a detection limit of $<50 \mathrm{mg} / \mathrm{L}$ after accounting for the dilution necessary to move samples from the shielded cells to ADS for analysis). A reanalysis of the slurry confirmed the presence of the phenylborate intermediates.

\footnotetext{
* This factor is the ratio of filtrate mass $(\mathrm{mg} / \mathrm{L})$ to Slurry mass $(\mathrm{mg} / \mathrm{L})$. It is calculated by the following formula: filtrate correction factor $=$ density slurry/density filtrate $*(1$-insoluble solids $)=1.162 / 1.164 *(1-0.0169)=0.981$
} 
Table 4 - HPLC Slurry Results for the Tank 48H sample

\begin{tabular}{|l|c|c|}
\hline Analyte & $\begin{array}{c}\text { Sample HTF-E-04- } \\
049 \text { and HTF-E- } \\
0050(\mathrm{mg} / \mathrm{L})\end{array}$ & $\begin{array}{c}1 \sigma \\
\text { Uncertainty } \\
(\mathrm{mg} / \mathrm{L})\end{array}$ \\
\hline TPB & 20,100 & 235 \\
\hline Calculated KTPB & 22,600 & 263 \\
\hline Phenol & 735 & 24.0 \\
\hline Biphenyl & 384 & 61.4 \\
\hline 3PB & 162 & 35.0 \\
\hline 2PB & 123 & 6.1 \\
\hline 1PB & 120 & 5.6 \\
\hline
\end{tabular}

Analytical uncertainty is $10 \%$ for all analytes except biphenyl (20\%)

\subsubsection{Radionuclide Composition}

Many of the radioisotopes are measured using ICP-MS methods. However, personnel determined ${ }^{90} \mathrm{Sr},{ }^{137} \mathrm{Cs}$ and gross alpha by radio-counting analyses for the Tank $48 \mathrm{H}$ slurry - see Table 5. The major radiation hazard in Tank $48 \mathrm{H}$ comes from the ${ }^{137} \mathrm{Cs}$, with a concentration of 1.54 $\mathrm{Ci} /$ gallon. This is equivalent to 367,000 total ${ }^{137} \mathrm{Cs}$ curies in Tank $48 \mathrm{H}$. The gross alpha analysis is used to calculate 4.13 total curies from alpha emitters in Tank $48 \mathrm{H}$.

Table 5 - Tank 48H Slurry Radiation Chemistry Analytical Results

\begin{tabular}{|l|c|c|}
\hline Analyte & $\begin{array}{c}\text { Sample } \\
\text { HTF-E-04-049 } \\
\text { and HTF-E-0050 }\end{array}$ & $\begin{array}{c}1 \sigma \\
\text { Uncertainty }\end{array}$ \\
\hline${ }^{137} \mathrm{Cs}(\mathrm{dpm} / \mathrm{mL})$ & $9.05 \mathrm{E}+08$ & $1.07 \mathrm{E}+07$ \\
\hline Gross Alpha $(\mathrm{dpm} / \mathrm{mL})$ & $1.01 \mathrm{E}+04$ & $6.51 \mathrm{E}+02$ \\
\hline
\end{tabular}

\subsubsection{Inductively Coupled Spectroscopy - Emission Spectroscopy}

Personnel determined the elemental composition of the digested slurry by ICP-ES. The major constituents found in the slurry include $\mathrm{Na}, \mathrm{K}, \mathrm{Al}$, and $\mathrm{B}$. The element sodium is present in the highest concentration at $74,900 \pm 660 \mathrm{mg} / \mathrm{L}(3.26 \pm 0.029 \mathrm{M})$. Aluminum and boron are present in appreciable levels. Elements measured below instrument detection limits include $\mathrm{Ag}, \mathrm{Be}, \mathrm{Cd}$, $\mathrm{Gd}, \mathrm{La}, \mathrm{Ni}, \mathrm{Pb}, \mathrm{V}$, and $\mathrm{Zr}$. The elemental results of the Tank $48 \mathrm{H}$ slurry sample are presented in Table 6. 
Table 6 - Major Elemental Constituents by ICP-ES in the Tank 48H Slurry Sample

\begin{tabular}{|c|c|c|}
\hline Analyte & $\begin{array}{c}\text { Sample } \\
\text { HTF-E-04-049 } \\
\text { and HTF-E-0050 }\end{array}$ & $1 \sigma$ Uncertainty \\
\hline $\mathrm{Al}$ & 2,240 & 0.00 \\
\hline B & 1,030 & 1.64 \\
\hline $\mathrm{Ba}$ & 2.52 & 0.03 \\
\hline $\mathrm{Ca}$ & 21.4 & 1.23 \\
\hline $\mathrm{Ce}$ & 6.89 & 0.11 \\
\hline $\mathrm{Cr}$ & 51.1 & 0.16 \\
\hline $\mathrm{Cu}$ & 2.97 & 0.16 \\
\hline $\mathrm{Fe}$ & 43.4 & 0.16 \\
\hline $\mathrm{K}$ & 2,380 & 16 \\
\hline $\mathrm{Mg}$ & 18.5 & 0.25 \\
\hline $\mathrm{Mn}$ & 6.38 & 0.06 \\
\hline Mo & 13.30 & 0.08 \\
\hline $\mathrm{Na}$ & 74,900 & 657 \\
\hline$P$ & 207 & 4.93 \\
\hline $\mathrm{S}$ & 245 & 1.64 \\
\hline $\mathrm{Sb}$ & 11.5 & 0.16 \\
\hline $\mathrm{Si}$ & 106 & 0.99 \\
\hline $\mathrm{Sn}$ & 22.1 & 2.05 \\
\hline $\mathrm{Sr}$ & 5.29 & 0.17 \\
\hline $\mathrm{Ti}$ & 840 & 0.82 \\
\hline $\mathrm{U}$ & 17.6 & 0.74 \\
\hline $\mathrm{Zn}$ & 12 & 0.08 \\
\hline
\end{tabular}

\subsubsection{Inductively Coupled Spectroscopy - Mass Spectroscopy}

SRNL performed three analyses of the Tank 48H slurry for actinides (with one of the samples analyzed at two different dilutions). The replicate samples showed excellent precision (Table 7).

${ }^{240} \mathrm{Pu},{ }^{241} \mathrm{Am},{ }^{243} \mathrm{Am}$, and ${ }^{244} \mathrm{Cm}$ are all less than the detection limits. ${ }^{238} \mathrm{Pu}$ can not be detected by this analytical method. 
Table 7 - Actinide Results for the Slurry Sample

\begin{tabular}{|l|c|c|}
\hline Analyte & $\begin{array}{c}\text { Sample } \\
\text { HTF-E-04-049 } \\
\text { and HTF-E-0050 }\end{array}$ & $1 \sigma$ Uncertainty \\
\hline $\mathrm{Np}-237, \mathrm{mg} / \mathrm{L}$ & $2.22 \mathrm{E}-01$ & $8.09 \mathrm{E}-03$ \\
\hline $\mathrm{Pu}-239, \mathrm{mg} / \mathrm{L}$ & $3.33 \mathrm{E}-02$ & $5.55 \mathrm{E}-03$ \\
\hline $\mathrm{U}-233, \mathrm{mg} / \mathrm{L}$ & $6.13 \mathrm{E}-02$ & $7.39 \mathrm{E}-03$ \\
\hline $\mathrm{U}-234, \mathrm{mg} / \mathrm{L}$ & $3.25 \mathrm{E}-01$ & $1.94 \mathrm{E}-02$ \\
\hline $\mathrm{U}-235, \mathrm{mg} / \mathrm{L}$ & $6.53 \mathrm{E}-01$ & $4.43 \mathrm{E}-02$ \\
\hline $\mathrm{U}-236, \mathrm{mg} / \mathrm{L}$ & $1.44 \mathrm{E}-01$ & $4.85 \mathrm{E}-03$ \\
\hline $\mathrm{U}-238, \mathrm{mg} / \mathrm{L}$ & $4.12 \mathrm{E}+00$ & $2.24 \mathrm{E}-01$ \\
\hline $\mathrm{U}$ Total, mg/L & $5.31 \mathrm{E}+00$ & $2.89 \mathrm{E}-01$ \\
\hline
\end{tabular}

We analyzed a slurry sample for metals $(\mathrm{Ag}, \mathrm{Pd}, \mathrm{Rh}$, and $\mathrm{Ru})$. The elemental results of the Tank $48 \mathrm{H}$ slurry sample are presented in Table 8 ,

\section{Table 8 - ICP-MS Catalytic Components Present in the Tank 48H Slurry Sample}

\begin{tabular}{|c|c|c|}
\hline \multicolumn{1}{|c|}{ Analyte } & $\begin{array}{c}\text { Sample } \\
\text { HTF-E-04-049 } \\
\text { and HTF-E-0050 }\end{array}$ & $1 \sigma$ Uncertainty \\
\hline Total Ag, mg/L & $1.88 \mathrm{E}-02$ & $2.12 \mathrm{E}-03$ \\
\hline Total Pd, mg/L & $9.28 \mathrm{E}-02$ & $6.78 \mathrm{E}-03$ \\
\hline Total Rh, mg/L & $1.53 \mathrm{E}-01$ & $1.61 \mathrm{E}-02$ \\
\hline Total $\mathrm{Ru}, \mathrm{mg} / \mathrm{L}$ & $3.80 \mathrm{E}-01$ & $8.43 \mathrm{E}-03$ \\
\hline
\end{tabular}

\subsubsection{Atomic Absorption Spectroscopy}

Personnel determined the elemental composition of the digested slurry by AA for K only. The element potassium is present in 2,650 $\pm 184 \mathrm{mg} / \mathrm{L}(0.068 \pm 0.0047 \mathrm{M})$.

\subsection{FILTRATE SAMPLE RESULTS}

ADS personnel analyzed the filtrate in duplicate for the Tank $48 \mathrm{H}$ sample. Personnel removed samples of the Tank $48 \mathrm{H}$ filtrate from the cells without dilution. ADS personnel diluted the filtrate as appropriate for the analyses. We report the analytical data, together with the one standard deviation $(1 \sigma)$ uncertainty. To compare the slurry results with the filtrate results, multiply filtrate results by 0.982 to convert them to a slurry basis. Note that a filtrate sample has been filtered to remove insoluble solids and a supernate sample has been pulled from an unslurried tank but has not been filtered. It is expected that supernate results from previous samples would have slightly higher insoluble solids concentrations. 


\subsubsection{Anion Analysis by Ion Chromatography}

Table 9 and Table 10 contain the measured values of the Tank $48 \mathrm{H}$ filtered sample. Table 9 includes the measured anion concentrations for the tank sample. Nitrate and nitrite concentrations are $0.216 \mathrm{M}$ and $0.465 \mathrm{M}$ respectively.

Table 9 - Anion Results for the Filtered Tank 48H sample, mg/L

Deleted: Tabl

Deleted: Table

Deleted: Tabl

\begin{tabular}{|l|c|c|}
\hline Analyte & $\begin{array}{c}\text { Sample } \\
\text { HTF-E-04-049 and } \\
\text { HTF-E-0050 }\end{array}$ & $1 \sigma$ Uncertainty \\
\hline $\mathrm{F}^{-}$ & $<20$ & NA \\
\hline $\mathrm{CO}_{2} \mathrm{H}^{-}$ & 680.0 & 428 \\
\hline $\mathrm{Cl}^{-}$ & 370 & 183 \\
\hline $\mathrm{NO}_{2}{ }^{-}$ & 30,400 & 1,800 \\
\hline $\mathrm{Br}^{-}$ & $<100$ & $\mathrm{NA}$ \\
\hline $\mathrm{NO}_{3}{ }^{-}$ & 18,750 & 926 \\
\hline $\mathrm{PO}_{4}{ }^{3-}$ & 916 & 222 \\
\hline $\mathrm{SO}_{4}{ }^{2-}$ & 528 & 210 \\
\hline $\mathrm{C}_{2} \mathrm{O}_{4}{ }^{2-}$ & 1613 & 116 \\
\hline
\end{tabular}

For comparison, Table 10 contains the measured values from this Tank $48 \mathrm{H}$ sample, but also Deleted: Table other recent measurements.

Table 10 - Comparison of Filtrate Anion Values, Molarity

\begin{tabular}{|c|c|c|c|}
\hline Anion & $\begin{array}{c}\text { HTF-E-04-049 and } \\
\text { HTF-E-0050 } \\
\text { Aug 04 }\end{array}$ & $\begin{array}{c}\text { HTF-E-03-127 } \\
\text { Sept 03 }\end{array}$ & $\begin{array}{c}\text { HTF-E-03-73 } \\
\text { June 03 }\end{array}$ \\
\hline $\mathrm{NO}_{3}{ }^{-}$ & 0.304 & 0.216 & 0.22 \\
\hline $\mathrm{NO}_{2}{ }^{-}$ & 0.649 & 0.465 & 0.45 \\
\hline $\mathrm{SO}_{4}{ }^{--}$ & 0.00643 & 0.00285 & 0.005 \\
\hline $\mathrm{Cl}^{-}$ & 0.0127 & 0.00351 & 0.005 \\
\hline $\mathrm{HCO}_{2}{ }^{-}$ & 0.0192 & 0.0096 & 0.009 \\
\hline $\mathrm{PO}_{4}{ }^{3-}$ & 0.0102 & 0.00542 & 0.016 \\
\hline $\mathrm{C}_{2} \mathrm{O}_{4}{ }^{2-}$ & 0.0183 & 0.0123 & 0.023 \\
\hline
\end{tabular}




\subsubsection{High Pressure Liquid Chromatography}

ADS completed analysis of the Tank $48 \mathrm{H}$ filtrate for tetraphenylborate and 14 of its common decomposition products. Only phenol at $526 \pm 2.47 \mathrm{mg} / \mathrm{L}$ occurs above the detection limit. Nitrobenzene, Nitrosobenzene, 4-phenylphenol, 2-phenylphenol, diphenylamine, biphenyl, oterphenyl, m-terphenyl, p-terphenyl, TPB, 3PB, 2PB, and 1PB all fell below detection limits (10 $\mathrm{mg} / \mathrm{L})$.

\subsubsection{Wet Chemistry}

ADS personnel analyzed the filtrate samples using titration methods, carbon analyses and density measurements. The total base is $2.04 \pm 0.071 \mathrm{M}$, the free hydroxide is $1.16 \pm 0.007 \mathrm{M}$, other base is $0.185 \pm 0.004 \mathrm{M}$, and carbonate is $0.492 \pm 0.001 \mathrm{M}$.

The free hydroxide concentration $(1.16 \mathrm{M})$ has increased since the September 2003 sample $(0.790 \mathrm{M})$ due to the addition of sodium hydroxide in October 2003.

The shielded cells technicians measured the Tank $48 \mathrm{H}$ filtrate density as $1.164 \pm 0.001 \mathrm{~g} / \mathrm{mL}$.

The total solids concentration of the Tank $48 \mathrm{H}$ filtrate was $17.68 \% \pm 0.14 \mathrm{wt} \%$. The total solids concentration of the Sept 2003 filtrate was $16.28 \pm 0.269 \mathrm{wt} \%$.

\subsubsection{Radionuclide Composition}

ADS personnel analyzed the filtered sample using radio-analytical methods. Cesium $\left({ }^{137} \mathrm{Cs}\right)$ is the major radioactive analyte in the filtrate at a concentration of $5.22 \mathrm{E}+05 \mathrm{nCi} / \mathrm{g}$. Table 11 summarizes the radionuclide concentrations. Other isotopes were not analyzed. Table 12 provides a comparison with previous sample results.

Table 11 - Tank 48H Filtrate Radiation Chemistry Data

\begin{tabular}{|l|c|c|}
\hline Analyte & $\begin{array}{c}\text { Sample } \\
\text { HTF-E-04-049 } \\
\text { and HTF-E-0050 }\end{array}$ & $\begin{array}{c}1 \sigma \\
\text { Uncertainty }\end{array}$ \\
\hline${ }^{137} \mathrm{Cs}(\mathrm{dpm} / \mathrm{mL})$ & $2.57 \mathrm{E}+07$ & $6.01 \mathrm{E}+04$ \\
\hline Gross Alpha $(\mathrm{dpm} / \mathrm{mL})$ & $2.00 \mathrm{E}+03$ & $3.89 \mathrm{E}+02$ \\
\hline
\end{tabular}

Table 12 - Radionuclide Comparison with Previous Samples

\begin{tabular}{|l|c|c|c|c|}
\hline $\begin{array}{l}\text { Sample ID } \\
\text { Radiochemical } \\
\text { Analysis }\end{array}$ & $\begin{array}{c}\text { Sample } \\
\text { HTF-E-04-049 and } \\
\text { HTF-E-0050 }\end{array}$ & $\begin{array}{c}\text { HTF-E-03-127 } \\
\text { 3-L sample } \\
\text { Sept. 2003 }\end{array}$ & $\begin{array}{c}\text { HTF-E-03-73 } \\
\text { June 2003 }\end{array}$ & $\begin{array}{c}\text { Previous Sample } \\
\text { Measurements }\end{array}$ \\
\hline${ }^{137} \mathrm{Cs}(\mathrm{nCi} / \mathrm{g})$ & $9.95 \mathrm{E}+03$ & $1.08 \mathrm{E}+04$ & $1.12 \mathrm{E}+04$ & 1.50 E+04 [Ref. 6] \\
\hline${ }^{90} \mathrm{Sr}(\mathrm{mg} / \mathrm{L})$ & Not Measured & $7.12 \mathrm{E}-06$ & $8.59 \mathrm{E}-06$ & $<2.44$ E-06 [Ref. 8] \\
\hline${ }^{99} \mathrm{Tc}(\mathrm{mg} / \mathrm{L})$ & Not Measured & $2.26 \mathrm{E}+00$ & $1.15 \mathrm{E}+00$ & 1.85 E+00 [Ref. 8] \\
\hline
\end{tabular}

\subsubsection{Atomic Absorption Spectroscopy}

ADS analyzed the filtered samples for potassium using atomic absorption spectroscopy. The $\mathrm{K}$ concentration of the Tank $48 \mathrm{H}$ filtrate was $255 \pm 24.7 \mathrm{mg} / \mathrm{L}$. 


\subsubsection{Inductively Coupled Spectroscopy - Emission Spectroscopy}

ADS determined the elemental composition of the filtrate by the ICP-ES method. The major constituents found in the filtrate included $\mathrm{Na}, \mathrm{Al}$, and $\mathrm{B}$. The element sodium is present in the highest concentration at $2.81 \mathrm{M}$. Aluminum and boron are present in appreciable levels. Elements measured below instrument detection limits include $\mathrm{Ag}, \mathrm{Ba}, \mathrm{Cd}, \mathrm{Ce}, \mathrm{Fe}, \mathrm{Gd}, \mathrm{La}, \mathrm{Li}$, $\mathrm{Mg}, \mathrm{Mn}, \mathrm{Ni}, \mathrm{Pb}, \mathrm{Sn}, \mathrm{Ti}, \mathrm{U}$, and $\mathrm{Zr}$. Table 13 provides the elemental results of the Tank $48 \mathrm{H}$ filtrate samples. Table 14 provides a comparison with historical data.

Table 13 - Tank 48H Filtrate ICP-ES Data

\begin{tabular}{|l|c|c|}
\hline Analyte & $\begin{array}{c}\text { Sample } \\
\text { HTF-E-04-049 } \\
\text { and HTF-E-0050 }\end{array}$ & $\begin{array}{c}1 \sigma \\
\text { Uncertainty }\end{array}$ \\
\hline $\mathrm{B}, \mathrm{mg} / \mathrm{L}$ & 412 & 12.7 \\
\hline $\mathrm{Cu}, \mathrm{mg} / \mathrm{L}$ & 1.014 & 0.221 \\
\hline $\mathrm{K}, \mathrm{mg} / \mathrm{L}$ & 372.5 & 53.0 \\
\hline $\mathrm{Na}, \mathrm{mg} / \mathrm{L}$ & 68,800 & 2,263 \\
\hline $\mathrm{Si}, \mathrm{mg} / \mathrm{L}$ & 4.675 & 0.361 \\
\hline
\end{tabular}

Table 14 - Major Elemental Constituents Present in the Tank 48H Filtrate Sample

\begin{tabular}{|c|c|c|c|c|c|}
\hline $\begin{array}{c}\text { Sample ID } \\
\text { Analysis }\end{array}$ & Units & $\begin{array}{c}\text { Sample } \\
\text { HTF-E-04-049 and } \\
\text { HTF-E-0050 }\end{array}$ & $\begin{array}{c}\text { HTF-E-03-127 } \\
\text { 3-L sample }\end{array}$ & $\begin{array}{c}\text { HTF-E-03-73 } \\
\text { Tk 48-2L-1 }\end{array}$ & 1998 Analyses $^{5}$ \\
\hline \multicolumn{6}{|c|}{ ICP-ES } \\
\hline A 1 & $\mathrm{M}$ & Not Measured & 0.0808 & 0.074 & 0.082 \\
\hline B & $\mathrm{M}$ & 0.038 & 0.0410 & 0.041 & 0.034 \\
\hline $\mathrm{Na}$ & $\mathrm{M}$ & 2.99 & 3.012 & 2.81 & 2.56 \\
\hline $\mathrm{S}$ & $\mathrm{M}$ & Not Measured & 0.00872 & 0.01 & NM \\
\hline $\mathrm{K}$ & $\mathrm{M}$ & 0.010 & 0.00633 & 0.01 & NM \\
\hline \multicolumn{6}{|c|}{$\mathbf{A A}$} \\
\hline $\mathrm{K}$ & M & 0.0065 & 0.00550 & 0.005 & 0.0004 \\
\hline $\mathrm{Cs}$ & $\mathrm{M}$ & Not Measured & $2.88 \mathrm{E}-06$ & $3.61 \mathrm{E}-06$ & NM \\
\hline
\end{tabular}

\subsection{IN-CELL SLURRY SAMPLE RESULTS}

Personnel performed analyses in the cells, because of the high radiation dose of the sample. Solids analyses, slurry titration and density analyses were completed in duplicate. These analytical data are summarized together with the one standard deviation $(1 \sigma)$ uncertainty. 


\subsubsection{In-cell Solids Analyses}

Based on the average of three analyses, the slurry contained total solids of $19.08 \pm 0.08 \%$ and the filtrate contained dissolved solids of $17.68 \pm 0.14 \%$. We calculate the value for the insoluble solids $(1.69 \pm 0.22 \mathrm{wt} \%)$ using the following formula. ${ }^{6}$

$$
\begin{aligned}
& \text { Insoluble Solids }=\frac{\text { total solids }-(100 \text {-total solids }) * \text { dissolved solids } / 100}{\text { dissolved solids } / 100)} \\
& \text { Insoluble Solids }=19.08-(100-19.08) * 17.68 / 100 /(1-17.68 / 100)=1.69
\end{aligned}
$$

Based on this calculation, the insoluble solids measurement was significantly lower than expected results based on previous analyses $(2.3 \%))^{7}$ The insoluble solids measurement has a range of 1.47 wt $\%$ to $1.91 \mathrm{wt} \%$ based on the calculated uncertainties. This overlaps with the sum of the measured KTPB plus MST concentration which has a range of $1.86 \mathrm{wt} \%$ to $2.34 \mathrm{wt} \%$.

\subsubsection{In-cell Density}

Technicians determined density from the average of duplicate measurements of the Tank $48 \mathrm{H}$ slurry. Based on these measurements, the density of the Tank $48 \mathrm{H}$ slurry equals $1.16 \pm 0.009$ $\mathrm{g} / \mathrm{mL}$.

\subsection{ANALYSIS OF DATA}

Completion of an anion and cation balance provides a consistency check on the data. By comparing filtrate potassium and cesium concentrations, one can obtain an understanding of the decomposition rate for the tetraphenylborate in Tank $48 \mathrm{H}$.

\subsection{TANK 48H ION BALANCE}

The sum of the major cations exceeds the sum of the major anions by $\sim 8 \%$, well within the accuracy typically experienced for such analyses. Table 15 sums the anions and cations using the filtrate analyses for the major components. 
Table 15 - Tank 48H Filtrate Anion/Cation Balance

\begin{tabular}{|l|c|c|c|}
\hline Analyte & Moles ions & $\begin{array}{c}\text { 16 Uncertainty, } \\
\text { moles }\end{array}$ & Method \\
\hline $\mathrm{AlO}_{2}{ }^{-}$ & 0.083 & 0.0000 & ICP-ES \\
\hline $\mathrm{BO}_{3}{ }^{3-}$ & 0.286 & 0.0005 & ICP-ES \\
$\mathrm{C}_{2} \mathrm{O}_{4}{ }^{2-}$ & 0.037 & 0.0013 & IC \\
\hline $\mathrm{Cl}^{-}$ & 0.010 & 0.0026 & IC \\
\hline $\mathrm{COOH}^{-}$ & 0.015 & 0.0048 & IC \\
\hline $\mathrm{CO}_{3}{ }^{2-}$ & 0.932 & 0.0007 & Titration \\
\hline $\mathrm{NO}_{2}{ }^{-}$ & 0.661 & 0.0320 & IC \\
\hline $\mathrm{NO}_{3}{ }^{-}$ & 0.302 & 0.0124 & IC \\
\hline $\mathrm{OH}^{-}$ & 1.155 & 0.0071 & Titration \\
\hline $\mathrm{PO}_{4}{ }^{3-}$ & 0.029 & 0.0012 & IC \\
\hline $\mathrm{SO}_{4}{ }^{2-}$ & 0.011 & 0.0011 & IC \\
\hline Total Anions & $\mathbf{3 . 5 2}$ & $\mathbf{0 . 0 6 4}$ & Calculation \\
\hline $\mathrm{K}^{+}$ & 0.007 & 0.0047 & AA \\
\hline $\mathrm{Na}^{+}$ & 3.259 & 0.0286 & ICP-ES \\
\hline $\begin{array}{l}\text { Total } \\
\mathbf{C a t i o n s}\end{array}$ & $\mathbf{3 . 2 7}$ & $\mathbf{0 . 0 3 3}$ & Calculation \\
\hline
\end{tabular}

\subsection{TANK 48H SOLUBLE POTASSIUM AND CESIUM}

The tetraphenylborate in Tank $48 \mathrm{H}$ continues to slowly decompose. As the tetraphenylborate decomposes, cesium and potassium are released from the insoluble solids and return to solution. As a result, the concentrations of cesium and potassium continue to increase over time. Data exist for the soluble cesium and potassium concentrations in the filtrate for the last eight years. Figure 1 and Figure 2 provide the measured values, with 10\% error bars. Note that we corrected the data for changes in Tank $48 \mathrm{H}$ volume (normalizing to the volume as of 240,000 , the volume on 11-3-96) and ${ }^{137} \mathrm{Cs}$ radioactive decay.

Based on the potassium data, the tetraphenylborate apparently continues to degrade at the same rate as experienced since 1996. The potassium data, shown on Figure 1, fits a linear curve $\left(r^{2}=0.993\right)$ almost as well as a $2^{\text {nd }}$ order polynomial $\left(r^{2}=0.995\right)$. The ${ }^{137} \mathrm{Cs}$ data, shown on Figure 2 , is no longer following the straight line. A better fit of the ${ }^{137} \mathrm{Cs}$ data fit is a $2^{\text {nd }}$ order polynomial curve $\left(r^{2}=0.993\right)$ better than a linear curve $\left(r^{2}=0.90\right)$. The drop in ${ }^{137} \mathrm{Cs}$ concentration could be caused by establishment of a new equilibrium due to decomposition or to the increase in ionic strength causing precipitation of cesium (due to the depletion of hydroxide followed by addition of sodium hydroxide to control corrosion). 
Figure 1 - K Soluble Concentration Increase Due to KTPB Decomposition

(K Data volume corrected to $\mathbf{2 4 0 , 0 0 0}$ gallons in Tank $48 \mathrm{H}$ )

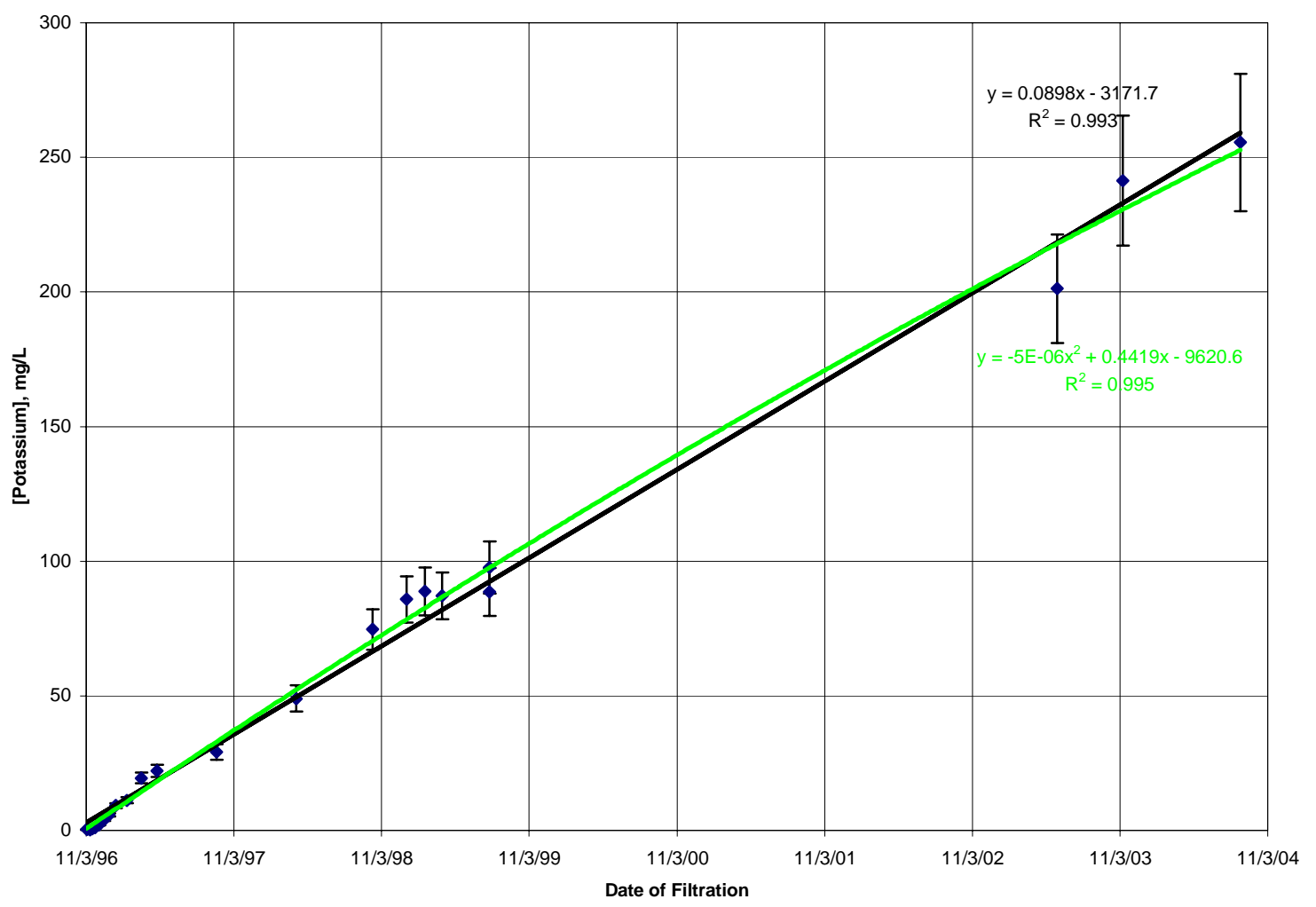


Figure $2-{ }^{137}$ Cs Concentration Increase Due to CsTPB Decomposition

\section{(Cs Data was corrected to 240,000 gal and adjusted for radioactive decay since 1996)}

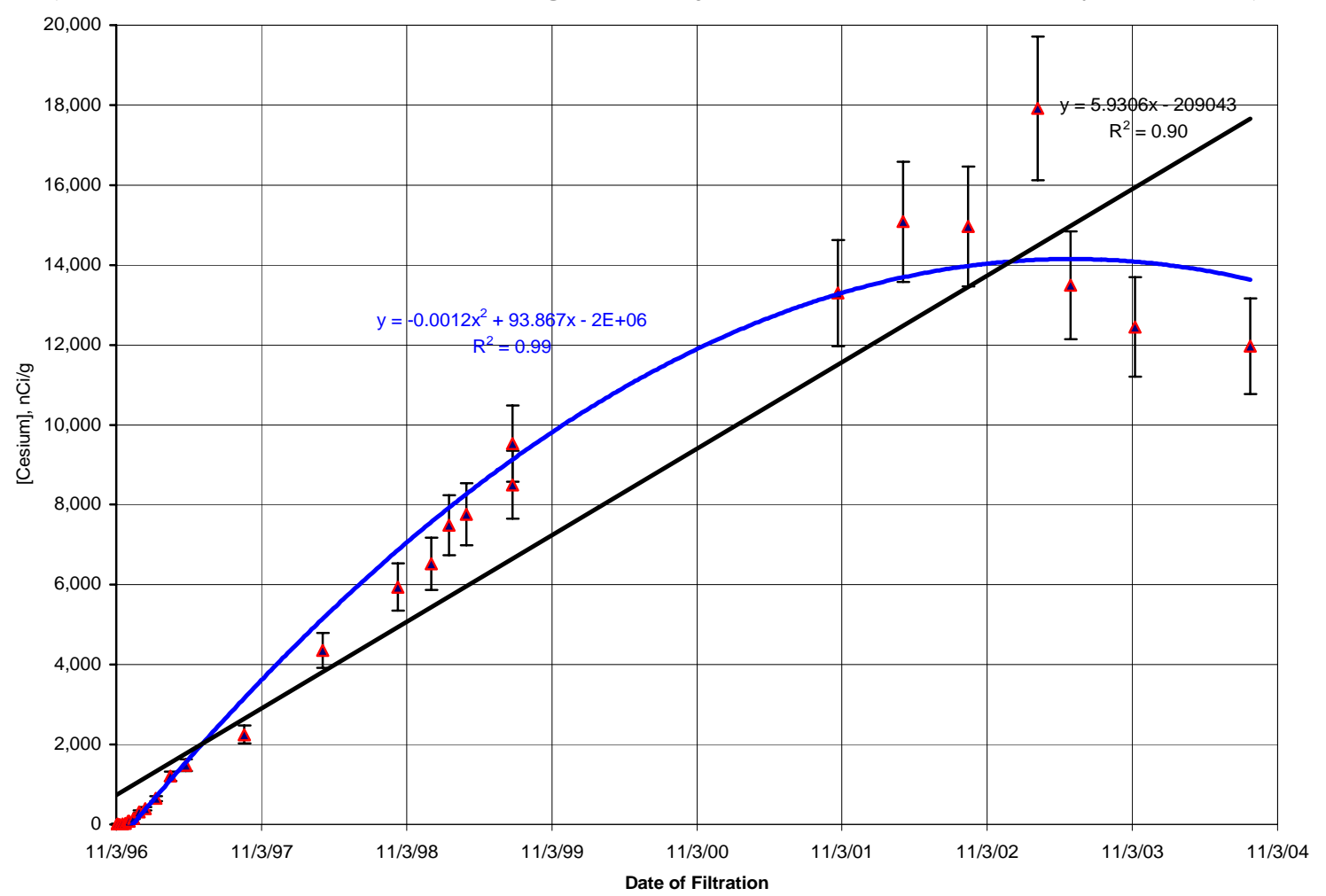

\subsection{SUMMARY}

Personnel analyzed samples taken from Tank 48H on August 23, 2004 for chemical and radiological constituents. This report documents the analytical results and analysis of this data.

The results demonstrate that samples pulled in September 2003 and August 2004 are very similar in chemical composition. The free hydroxide concentration, sodium concentration, soluble solids and density have all increased as expected due to the addition of 6,424 gallons of $50 \mathrm{wt} \%$ sodium hydroxide on October 30, 2003.

The tetraphenylborate in Tank $48 \mathrm{H}$ continues to slowly decompose at a rate of approximately $0.0898 \mathrm{mg} \mathrm{K} / \mathrm{L} /$ day or $1.3 \%$ TPB decomposition per year. This is consistent with the measured decomposition over the last eight years.

The analyses requested were primarily designed to support an in-tank catalyzed hydrolysis process and the actual waste testing of the hydrolysis and aggregation process alternatives. The Tank $48 \mathrm{H}$ sample contains $9.28 \mathrm{E}-02 \pm 6.78 \mathrm{E}-03 \mathrm{mg} / \mathrm{L} \mathrm{Pd}, 2.97 \pm 0.156 \mathrm{mg} / \mathrm{L} \mathrm{Cu}$ and $20.4 \pm 0.86$ $\mathrm{mg} / \mathrm{L} \mathrm{Hg}$. Additional analyses may be required for alternative processes such as Aggregation.

Data collected during sampling is summarized in Appendix A. The Tank $48 \mathrm{H}$ analytical results are summarized in Appendix B. 


\subsection{ACKNOWLEGEMENTS}

This task required the support of a large team of people. We thank the following individuals but note that many others assisted in completing this task.

We thank the dedicated Shielded Cells Technicians Debbie Burckhalter, Nan Stanley and Dee Wheeler for receiving the Tank $48 \mathrm{H}$ sample, completing the analyses in the cells as requested, and preparing the hundreds of samples for transfer to ADS.

We thank the following personnel in the Analytical Development Section for analyzing samples in a busy time period. We list the researchers involved but omit the many technicians supporting them to complete this task on schedule. Thanks to Leigh Brown, Jon Kuhns, Kim Mitchell, John Young, Tom White, Robert Ray, Curtis Johnson, David DiPrete, Ceci DiPrete, June Hart, Bill Boyce, Chuck Coleman, and Damon Click.

We appreciate the continued support of our WPT technicians, Kim Wyszynski and Liz Coleman, who prepared the sample bottles for the shielded cells technicians and verified that the written instructions accomplished the intended tasks.

We appreciate the support of the Tank 48H team, especially Rick Fowler, Steve Strohmeier, Ben Dean, Delane Maxwell, Dennis Conrad, and Bernice Rogers for their technical support in helping us accomplish this task. 


\subsection{REFERENCES}

1 T. B. Peters, D. P. Lambert, M. E. Smith, and S. D. Fink, "Task Technical and Quality Assurance Plan for Destruction of Tetraphenylborate in Tank 48H", WSRC-RP-200300396, Rev. 1, June 10, 2003.

2 Tank 48H 10 Liter Sample Analyses, SP-TTR-2004-00020, August 4, 2004.

3 D. P. Lambert, T. B. Peters, M. S. Hay, S. D. Fink, "Task Technical and Quality Assurance Plan for Analysis and Acceptance of Tank 48H Sample", WSRC-RP-200400598, Revision 0, August 2004.

4 W. B. Dean, “Tank 48H Dissolution Sampling Plan”, CBU-SPT-2003-00104, Rev. 0, May 15, 2003.

5 D. T. Hobbs, et al., "Radioactive Testing Results in Support of the In-Tank Precipitation Facility", WSRC-TR-98-00070, Rev. 0, April 2, 1998.

6 C. J. Coleman, D. D. Walker, "Statistical Study of Weight \% Insoluble Methods for In-Tank Precipitation (ITP) Cold Run Support", WSRC-TR-92-256, December 9, 1992.

7 D. D. Walker, W. T. Boyce, C. J. Coleman, D. P. DiPrete, T. B. Edwards, A. A. Ekechuckwu, C. W. Hsu, S. F. Peterson, L. L. Tovo, and M. J. Whitaker, "Tank 48H Waste Composition and Results of Investigations of Analytical Methods", WSRC-TR97-0063, April 2, 1997. 


\section{Appendix A \\ Data Collected during Sampling}

Figure A-1 - Temperature and Pump Data during Sampling

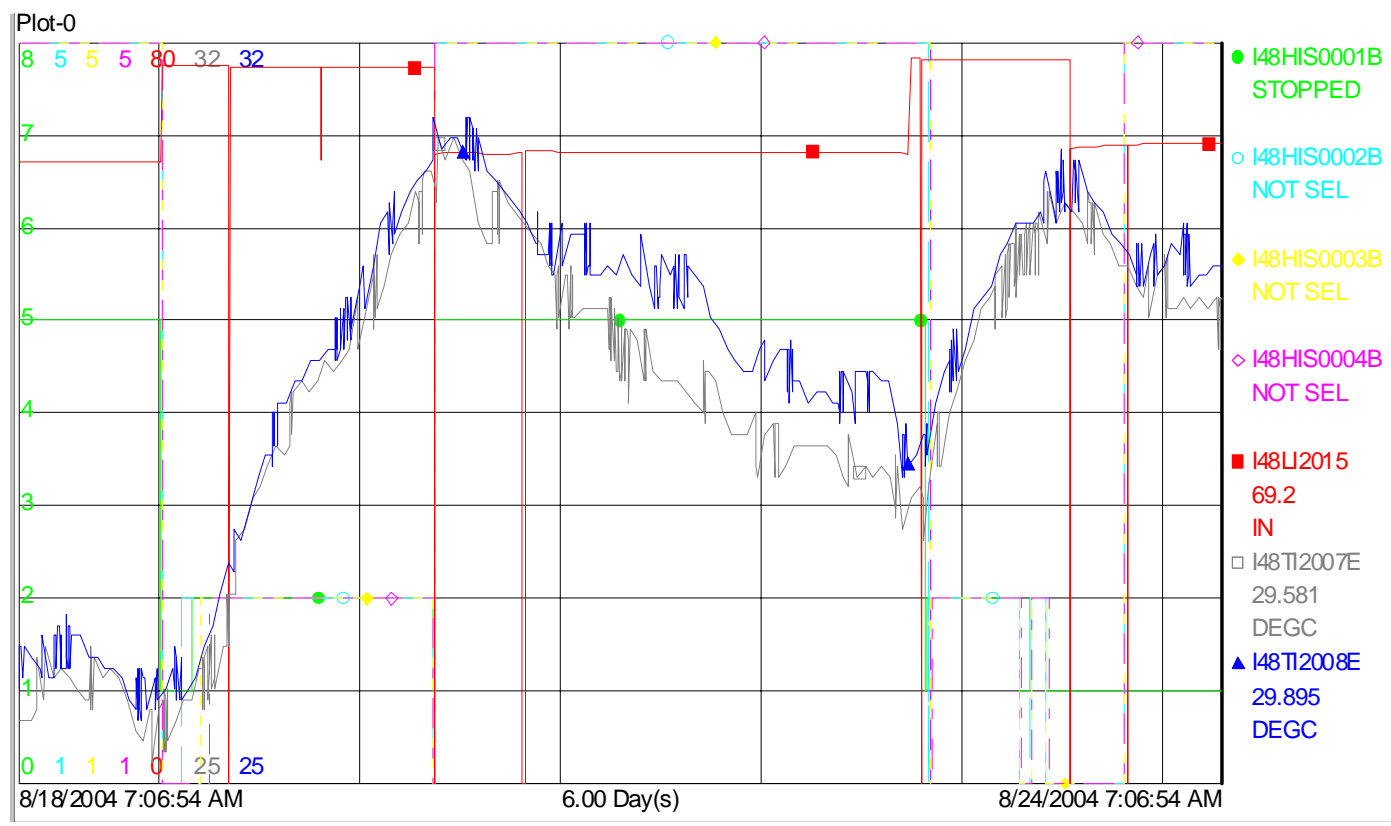

Table A-1 - Pump Start and Stop Time for Samples HTF-E-04-049 and 04-050

\begin{tabular}{|c|c|c|c|c|}
\hline Pump & Start time & Stop Time & Duration \#1, hrs & Downtime, hrs \\
\hline B1 & $8 / 19 / 042: 51$ & $8 / 20 / 048: 42$ & 30 & 60 \\
& $8 / 22 / 0419: 58$ & $8 / 22 / 047: 01$ & 11 & 13 \\
& $8-23-0420: 08$ & $8-23-0421: 58$ & 2 & 60 \\
\hline B4 & $8 / 19 / 043: 53$ & $8 / 20 / 047: 48$ & 28 & 13 \\
& $8 / 22 / 0420: 13$ & $8 / 22 / 047: 30$ & 11 & \\
& $8-23-0420: 13$ & $8-23-0422: 03$ & 2 & 60 \\
V1 & $8 / 19 / 045: 08$ & $8 / 20 / 048: 15$ & 27 & 13 \\
& $8 / 22 / 0420: 27$ & $8 / 22 / 047: 30$ & 11 & 60 \\
& $8-23-0420: 21$ & $8-23-0422: 03$ & 2 & 13 \\
\hline V2 & $8 / 19 / 046: 00$ & $8 / 20 / 048: 20$ & 26 & 11 \\
& $8 / 22 / 0420: 27$ & $8 / 22 / 047: 30$ & 2 & \\
& $8-23-0420: 28$ & $8-23-0422: 28$ & &
\end{tabular}

The tank level increased from 67.2 to 69.1 inches as a result of the sampling. This is a volume increase of 6,670 gallons. The pumps operated for a total time of 163 hours for a calculated inleakage of 41 gallons per hour. 
Table A-3 -- Data collected During June sampling

\begin{tabular}{|l|c|c|}
\hline & \multicolumn{2}{|c|}{ Bearing Water flow } \\
\hline Pump & $\mathrm{mL} / \mathrm{min}$ & gallons/hr \\
\hline V2 & \multicolumn{2}{|c|}{ Not recorded } \\
\hline V1 & 150 & 2.4 \\
\hline B4 & 150 & 2.4 \\
\hline B1 & 200 & 3.2 \\
\hline Total & $>500$ & $>8.0$ \\
\hline
\end{tabular}


Appendix B - Tank 48H Sample Results Summary (Results > 1 mg/L)

\begin{tabular}{|l|c|c|c|}
\hline Analyte & Slurry & Filtrate & Source \\
\hline Volume, gal & 239,031 & NM & Tank 48H \\
\hline Density, mg/L & 1.162 & 1.164 & Density \\
\hline Total Solids, wt \% & $19.08 \%$ & $17.68 \%$ & Solids \\
\hline Total Insolubles & $1.69 \%$ & NM & Calculation \\
\hline KTPB, wt \% & $1.95 \%$ & $<0.001 \%$ & HPLC \\
\hline MST solids, wt \% & $0.15 \%$ & NM & ICP-ES \\
\hline Anions & & & \\
\hline Free Hydroxide, M & $\mathrm{NM}$ & 1.16 & Titration \\
\hline Carbonate, $\mathrm{M}$ & $\mathrm{NM}$ & 0.492 & Titration \\
\hline Nitrite, $\mathrm{M}$ & $\mathrm{NM}$ & 0.649 & Anion \\
\hline Nitrate, $\mathrm{M}$ & $\mathrm{NM}$ & 0.304 & Anion \\
\hline Oxalate, $\mathrm{mg} / \mathrm{L}$ & $\mathrm{NM}$ & 1,613 & Anion \\
\hline Formate, $\mathrm{mg} / \mathrm{L}$ & $\mathrm{NM}$ & 680 & Anion \\
\hline Chloride, mg/L & $\mathrm{NM}$ & 370.25 & Anion \\
\hline Phosphate, mg/L & $\mathrm{NM}$ & 915.75 & Anion \\
\hline Sulfate, mg/L & $\mathrm{NM}$ & 527.5 & Anion \\
\hline Organic Species & & & \\
\hline TPB Anion, mg/L & 20,100 & $<10$ & HPLC \\
\hline 3PB, mg/L & 162 & $<10$ & HPLC \\
\hline 2PB, mg/L & 123 & $<10$ & HPLC \\
\hline PBA, mg/L & 120 & $<10$ & HPLC \\
\hline PHENOL, mg/L & 735 & 529 & HPLC \\
\hline Nitrobenzene, mg/L & $<50$ & $<10$ & HPLC \\
\hline Nitrososbezene, mg/L & $<50$ & $<10$ & HPLC \\
\hline 4phenylphenol, mg/L & $<50$ & $<10$ & HPLC \\
\hline 2phenylphenol, mg/L & $<50$ & HPLC \\
\hline Diphenylamine, mg/L & $<50$ & HPLC \\
\hline Biphenyl, mg/L & 384 & HPLC \\
\hline o-terphenyl, mg/L & $<50$ & HPLC \\
\hline m-terphenyl, mg/L & $<50$ & HPLC \\
\hline p-terphenyl, mg/L & $<50$ & HPLC \\
\hline
\end{tabular}




\begin{tabular}{|l|c|c|c|}
\hline Metals & Slurry & Filtrate & Source \\
\hline Potassium, M & 0.068 & 0.0061 & AA \\
\hline Hg, mg/L & 22.0 & NM & AA \\
\hline Sodium, M & 3.26 & 2.99 & ICP-ES \\
\hline Potassium, M & 0.061 & 0.0095 & ICP-ES \\
\hline Aluminum, mg/L & 2,242 & NM & ICP-ES \\
\hline Boron, mg/L & 1,030 & 412 & ICP-ES \\
\hline Sulfur, mg/L & 245.08 & NM & ICP-ES \\
\hline Phosphorus, mg/L & 206.75 & NM & ICP-ES \\
\hline Silicon, mg/L & 106.28 & 4.675 & ICP-ES \\
\hline Iron, mg/L & 43.44 & $<0.709$ & ICP-ES \\
\hline Chromium, mg/L & 51.11 & NM & ICP-ES \\
\hline Magnesium, mg/L & 18.53 & NM & ICP-ES \\
\hline Calcium, mg/L & 21.43 & NM & ICP-ES \\
\hline Molybdenum, mg/L & 13.30 & NM & ICP-ES \\
\hline Antimony, mg/L & 11.50 & NM & ICP-ES \\
\hline Zinc, mg/L & 11.91 & NM & ICP-ES \\
\hline Manganese, mg/L & 6.38 & NM & ICP-ES \\
\hline Strontium, mg/L & 5.29 & NM & ICP-ES \\
\hline Barium, mg/L & 2.52 & NM & ICP-ES \\
\hline Copper, mg/L & 2.97 & 1.014 & ICP-ES \\
\hline Total Ag, mg/L & $1.88 E-02$ & $2.12 E-03$ & ICP-MS \\
\hline Total Pd, mg/L & $9.28 E-02$ & $6.78 E-03$ & ICP-MS \\
\hline Total Rh, mg/L & $1.53 E-01$ & $1.61 E-02$ & ICP-MS \\
\hline Total Ru, mg/L & $3.80 E-01$ & $8.43 E-03$ & ICP-MS \\
\hline Total Cd, mg/L & $2.16 E-02$ & $1.57 E-02$ & ICP-MS \\
\hline Total Hg, mg/L & $4.45 E+00$ & $6.73 E-02$ & ICP-MS \\
\hline Np-237, mg/L & $2.22 E-01$ & $8.09 E-03$ & ICP-MS \\
\hline Pu-239, mg/L & $3.33 E-02$ & $5.55 E-03$ & ICP-MS \\
\hline U-233, mg/L & $6.13 E-02$ & $7.39 E-03$ & ICP-MS \\
\hline U-234, mg/L & $3.25 E-01$ & $1.94 E-02$ & ICP-MS \\
\hline U-235, mg/L & $6.53 E-01$ & $4.43 E-02$ & ICP-MS \\
\hline U-236, mg/L & $1.44 E-01$ & $4.85 E-03$ & ICP-MS \\
\hline U-238, mg/L & $4.12 E+00$ & $2.24 E-01$ & ICP-MS \\
\hline U Total, mg/L & $5.31 E+00$ & $2.89 E-01$ & ICP-MS \\
\hline
\end{tabular}


WSRC-TR-2004-00514, Rev 1

\begin{tabular}{|c|c|c|c|c|c|c|c|}
\hline R. A. & Adams & 241-162H, Rm. 4 & (E) & D. B. & Little & 703-H, Rm. 3 & (E) \\
\hline J. W. & Barber & 704-2H, Rm. 197 & (E) & S. R. & Loflin & 773-41A, Rm. 223 & (E) \\
\hline J. L. & Barnes & 704-S, Rm. 19 & (E) & N.P. & Malik & 704-26F, Rm. 11 & (E) \\
\hline M. J. & Barnes & 773-A, Rm. B-132 & (E) & J. C. & Marra & 773-42A, Rm. 173 & (E) \\
\hline W. M. & Barnes & 704-56H, Rm. 164 & (E) & D. J. & Martin & 703-H, Rm. 84 & (E) \\
\hline S. M. & Blanco & 766-H. Rm. 2434 & (E) & K. B. & Martin & 773-42A, Rm. 14 & (E) \\
\hline L. R. & Bragg & 766-H, Rm. 2434 & (E) & C. J. & Martino & 735-11A, Rm. 121 & (E) \\
\hline T. E. & Britt & 742-4G, Rm. 3 & (E) & & & & \\
\hline H. L. & Bui & 742-4G, Rm. 3 & (E) & G. J. & Matis & 766-H, Rm. 1066F & (E) \\
\hline S. G. & Campbell & 703-H, Rm. 107 & (E) & D. & Maxwell & 766-H, Rm. 2231 & (E) \\
\hline $\mathrm{L}$. & Carey & 766-H, Rm. 2005A & (E) & D. J. & McCabe & 73-42-A, Rm. 153 & (E) \\
\hline J. T. & Carter & 703-H, Rm 122 & (E) & J. W. & McCullough & 766-H, Rm. 2411 & (E) \\
\hline W. D. & Clark & 766-H, Rm. 2412 & (E) & L. T. & McGuire & 766-H, Rm. 2441 & (E) \\
\hline S. L. & Clifford & 766-H, Rm. 2443 & (E) & M. S. & Miller & 772-7B, Rm. 6 & (E) \\
\hline J. J. & Connelly & 773-41A, Rm. 231 & (E) & C. A. & Nash & 773-42A, Rm. 182 & (E) \\
\hline D. T. & Conrad & 766-H, Rm. 2007 & (E) & L. M. & Nelson & 773-43A, Rm. 222 & (E) \\
\hline D. R. & Cox & 730-2B, Rm. 118 & (E) & M. A. & Norato & 704-27S, Rm. 6 & (E) \\
\hline A. D. & Cozzi & 773-43A, Rm. 218 & (E) & M. R. & Norton & 66-H, Rm. 2002 & (E) \\
\hline C. L. & Crawford & 773-41A, Rm. 180 & (E) & J. E. & Occhipinti & 704-S, Rm. 18 & (E) \\
\hline D. A. & Crowley & 773-A, Rm. A-262 & (E) & L. D. & Olson & 703-H, Rm. 5 & (E) \\
\hline N. R. & Davis & 766-H, Rm. 1006 & (E) & L. M. & Papouchado & 773-A, Rm. A-263 & (P) \\
\hline W. B. & Dean & 766-H, Rm. 2243 & (E) & T. B. & Peters & 773-42A, Rm. 128 & (E) \\
\hline V. G. & Dickert & 703-H, Rm. 4 & (E) & J. A. & Pike & 703-H, Rm. 99 & (E) \\
\hline C. L. & Donahue & 241-162H, Rm. 6 & (E) & M. R. & Poirier & 773-42A, Rm. 123 & (E) \\
\hline M. D. & Drumm & 766-H, Rm. 2050 & (E) & S. H. & Reboul & 703-H, Rm. 84 & (E) \\
\hline M. C. & Duff & 773-43A, Rm. 217 & (E) & T. R. & Reynolds & 704-S, Rm. 65 & (E) \\
\hline C. R. & Dyer & 766-H, Rm. 2426 & (E) & M.A. & Rios-Armstrong & 766-H, Rm 2054 & (E) \\
\hline R. E. & Eibling & 999-W, Rm. 335 & (E) & S. J. & Robertson & 766-H, Rm. 2500 & (P) \\
\hline G. N. & Eide & 241-121H, Rm. 6 & (E) & B. C. & Rogers & 766-H, Rm. 2008 & (E) \\
\hline H. H. & Elder & 703-H, Rm. 95 & (E) & R. A. & Runnels & 766-H, Rm. 2011 & (E) \\
\hline S. D. & Fink & 773-A, Rm. B-112 & $(E, P)$ & P. J. & Ryan & 704-61S, Rm. 6 & (E) \\
\hline F. F. & Fondeur & 773-A, Rm. B-124 & (E) & E. & Saldivar & 766-H, Rm. 2004 & (E) \\
\hline R. C. & Fowler & 703-H, Rm. 98 & (E) & S. C. & Shah & 766-H, Rm. 2037 & (E) \\
\hline L. M. & Fox & 703-H, Rm. 3 & (E) & D. C. & Sherburne & 704-S, Rm. 18 & (E) \\
\hline M.W. & Geeting & 766-H, Rm. 2035 & (E) & T. J. & Spears & 766-H, Rm. 2015 & (E) \\
\hline B. A. & Gifford & 766-H, Rm. 1066D & (E) & R. H. & Spires & 766-H, Rm. 2003 & (E) \\
\hline A. P. & Giordano & 703-H, Rm 79 & (E) & M. E. & Stallings & 773-A, Rm. B-117 & (E) \\
\hline J. C. & Griffin & 773-A, rm. A-231 & (E) & W. E. & Stevens & 773-A, Rm. A-261 & (E) \\
\hline B. A. & Hamm & 766-H, Rm. 2237 & (E) & S. J. & Strohmeier & 766-H, Rm. 2022 & (E) \\
\hline H. D. & Harmon & 766-H, Rm. 2014 & (P) & S. G. & Subosits & 766-H, Rm. 2052 & (E) \\
\hline K. D. & Harp & 755-H, Rm. 1066B & (E) & P. C. & Suggs & 766-H, Rm. 2436 & (E) \\
\hline E. W. & Harrison & 766-H, Rm. 2034 & (E) & G. A. & Taylor & 703-H, Rm. 96 & (E) \\
\hline K. A. & Hauer & 703-H, Rm. 11 & (E) & S. A. & Thomas & 766-H, Rm. 2016 & (E) \\
\hline D. T. & Herman & 735-11A, Rm. 104 & (E) & P. J. & Valenti & 730-4B, Rm. 2062 & (E) \\
\hline P. J. & Hill & 766-H, Rm. 1066C & (E) & W. B. & Van-Pelt & 704-S, Rm. 16 & (E) \\
\hline R. N. & Hinds & 766-H, Rm. 2430 & (E) & D. D. & Walker & 773-A, Rm. B-124 & (E) \\
\hline D. T. & Hobbs & 773-A, Rm. B-117 & (E) & A. $\mathrm{O}$. & Waring & 766-H, Rm. 2423 & (E) \\
\hline E. W. & Holtzscheiter & 773-A, Rm. A-230 & (E) & F. A. & Washburn & 766-H, Rm. 2054 & (E) \\
\hline C. M. & Jantzen & 773-A, Rm. B-104 & (E) & V. B. & Wheeler & 766-H, Rm. 2438 & (E) \\
\hline R. T. & Jones & 766-H, Rm. 2463 & (E) & G. G. & Wicks & 773-A, Rm. B-129 & (E) \\
\hline E. T. & Ketusky & 703-H, Rm. 83 & (E) & W. R. & Wilmarth & 773-42A, Rm. 171 & (E) \\
\hline D. P. & Lambert & 773-A, Rm. B-132 & (E) & G. C. & Whinship & 766-H, Rm. 2024 & (E) \\
\hline C. A. & Lanigan & 766-H, Rm. 2440B & (E) & LWP File & & $773-42 \mathrm{~A}$ & $(\mathbf{E}, \mathbf{P})$ \\
\hline C. A. & Langton & 773-43A, Rm. 219 & (E) & STI & & 703-43A (E) (P 3 c & \\
\hline T. T. & Le & 766-H, Rm. 2237 & (E) & & & & \\
\hline R. K. & Leugemors & 766-H, & (E) & & & & \\
\hline
\end{tabular}

